\title{
Religion on the rise again? A longitudinal analysis of religious dimensions in election manifestos of Western European parties
}

\author{
Jakob Schwörer (i) \\ Institute for Political Science, Leuphana Universität Lüneburg, Lüneburg, Germany \\ Belén Fernández-García \\ Intituto de Ciências Sociais, Universidade de Lisboa, Portugal
}

\begin{abstract}
Several scholars suggest that religion is on the rise in party competition due to the upswing of radical right parties presenting themselves as defender of Christianity against a Muslim threat. The lack of comparative and longitudinal studies calls for a systematic investigation of parties' religious references in order to know whether religion indeed is on the rise in party politics. Conducting a partially computer-based quantitative content analysis of $7 \mathrm{I}$ election manifestos in five countries since the 1980s, we provide empirical evidence that religion is recently gaining salience in party competition. The study reveals that we are experiencing the evolution of a new religious cleavage originating from the exclusion of Islam and resulting in an emphasis on Christian roots and values and in a strategic use of secular arguments by the radical right. The findings further suggest that mainstream parties responded to these religious discourses by incorporating religious elements in their own election manifestos.
\end{abstract}

\section{Keywords}

content analysis, manifestos, political parties, radical right, religion

\section{Introduction}

In the last decades, radical right parties (RRP) increased their vote share in Western Europe and even entered national governments in some countries (Lewis et al., 2018). While most of these political actors are characterised as populist - opposing a corrupt political elite with an honest and moral people - they are best described as nativist or sometimes ethnic nationalist in ideological terms (Mudde, 2007; Rydgren, 2017). Nativists divide society in native in-groups and non-native out-groups based on national, ethnical, religious or cultural traits. Which groups are framed as natives and non-natives can change over time and differs between RRP of different world regions.

Yet, while traditionally, immigrants and certain national groups have been excluded from the native society, the Western European radical right recently has started to attack new religiously framed out-groups. There is a common understanding that far right parties have 'made a comprehensive political investment in Islamophobia, transforming it into an extreme obsessional prejudice at the heart of its discourses and political programs' (Kallis, 2018: 47). Moreover, several scholars argue that the focus on Islam as a new religious out-group resulted in the construction of new religiously framed native in-groups. On the one hand, the nativists' preoccupation with Islam leads to the construction of a Christian in-group and references to a Christian civilizational identity (Brubaker, 2017; Forlenza, 2019; Roy, 2016a). On the other hand, RRP are expected to highlight their secular stances due to their

Paper submitted 20 March 2020; received revised 28 May 2020; accepted for publication 9 June 2020

\section{Corresponding author:}

Jakob Schwörer, Institute for Political Science, Leuphana Universität Lüneburg, Universitätsallee I, 2 I 335 Lüneburg, Germany.

Email: jakob.schwoerer@leuphana.de 
concern 'about the public visibility of Muslim symbols and practices' (Brubaker, 2017: 1198). Islam is accused of not being secular enough for being part of the secular Western world (Bader, 2007: 47). Thus, according to academics, religious dimensions in party competition are gaining relevance due to the rise of RRP and their use of discourses about Islam, Christianity and secularism, or speaking with Minkenberg (2018: 366), 'religion is on the rise again'.

This observation indicates the emergence of a new religious cleavage in party politics. Originally, party systems in Western Europe were characterised - among others - by the traditional cleavage between church and state leading to the establishment of anti-clerical and liberal parties attempting to reduce the influence of the church on the one side and parties defending the role and privileges of the church on the other (Knutsen, 2004; Lipset and Rokkan, 1967). The assumption about the rise of religion in party politics mostly addresses a different dimension of party communication, namely references to religious in- and out-groups.

Yet, despite the widespread assumption that the radical right increasingly refers to such groups, there is little empirical evidence in terms of systematic comparative and longitudinal analyses so far. This study attempts to partially fill this research gap. We measure religious references of radical right and mainstream parties over time in 5 different Western European countries conducting content analyses of 71 election manifestos. We assess whether religious communication regarding references to secularism, Christianity and Islam increased since the 1980s and particular since the turn of the century among radical right, centre-left and centre-right parties in France, the United Kingdom, Austria, Switzerland and Italy.

\section{Nativism and religion}

Religious cleavages characterised European party systems for a long time. The original religious conflict in European societies goes back to the Protestant Reformation, which caused tensions between Protestants and Catholics (Knutsen, 2004; Lipset and Rokkan, 1967). The French Revolution renewed religious conflicts, but in a different dimension. Religious forces - Protestants and Catholics now mobilised against liberal and secular efforts to reduce the influence of the church on the state. Not only in France but throughout Europe 'Conflicts over church and state control, the legislation of mandatory state education, and disestablishment of state religion' emerged (Knutsen, 2004: 98; see also: Lipset and Rokkan, 1967: 15). These conflicts were often intense - as for example in Germany and Switzerland - and led to the formation of new parties in the early 20th century defending Catholic or Christian interests (Knutsen, 2004). The religious cleavage remained salient in post-war Europe, however, mostly for individuals and as a factor influencing party cohesion (Ozzano, 2019:
67). For party communication and campaigning, religious issues hardly played a role (Knutsen 2004: 99). Talking about Christian Democratic Parties, Kalyvas and Van Kersbergen (2010: 188) point out that "vague formulations such as "religious inspiration" or "values of Christian civilization" are today the sole references to religion in the official discourse'. At present, however, 'the Islam's arrival' in Europe reopens debates about politics and religion (Cesari, 2011: 38), this time mostly due to RRP's references to religious in- and out-groups, which further provoke new 'radical' secular discourses (Moodod, 2010).

Notwithstanding, Western European RRP - and in particular those focused on in this article (French National Rally, Freedom Party of Austria, Swiss People's Party, United Kingdom Independence Party and the Northern League) - did not emphasise a religious agenda from their beginning (Minkenberg, 2018: 377). Some of these parties - such as the National Rally - have actually been influenced by 'paganist ideas and symbols' (Brubaker, 2017: 1198) or are even described as anti-clerical at the beginning like the Freedom Party of Austria (Rosenberger and HadjAbdou, 2013).

The fact that these parties refer to religious elements in their discourses can be explained by their nativist ideology, which separates society in native in- and non-native outgroups (Schwörer and Romero-Vidal, 2020). Mudde (2007: 19) defines nativism as an ideology 'which holds that states should be inhabited exclusively by members of the native group ("the nation") and that non-native elements (persons and ideas) are fundamentally threatening to the homogenous nation-state'. ${ }^{1}$ Nativist parties oppose 'insiders and outsiders', "'people like us", those who share our way of life, and those on the outside who are said to threaten our way of life' (Brubaker, 2017: 1192). Yet, nativism is a flexible ideology and in- as well as outgroups are framed differently in the course of time - depending on who or what is perceived as a foreign threat and who or what needs to be protected. In this sense, it is argued that 'nativism can, on occasion, lead to a defence of the West, Europe, Christianity (or sometimes the Judeo-Christian tradition), humanism, or secular values' (Bar-on, 2018: 25). Several scholars argue that Islam and Muslims are framed as new religious out-groups particularly since the September 11 attacks, which triggered fear about the supposed foreign and unfamiliar Islamic religion (Bleich, 2009; Kallis, 2018). Cesari (2011:21), for example, points out that 'modern and secular anti-Islamic discourse and practice' is 'intensifying after $9 / 11$ '. Further jihadist attacks in Europe - among others in London in July 2005, Paris in January and November 2015, Berlin in February 2017 or London in June 2017 - have increased public fear about Muslims and Islam as well as discourses about them lead by the radical right (Kaya and Tecmen, 2019). Likewise, further European domestic factors might have put Islam at the centre of the radical right's agenda: for example, the EU's 
accession negotiations with Turkey - depicted as an Islamic country by the radical right (Rosenberger and HadjAbdou, 2013) -starting in 2005 as well as the so called 'refugee crisis' from 2015 (Osiewicz, 2017) and growing migratory flows from Muslim countries in the 2010's. In this sense, Islamophobia tends to overlap with anti-immigration discourses since Muslims in Europe often have an immigration background (Cesari, 2011).

Almost simultaneously, Christians or the supposed Christian identity and values of the West - which need to be protected against the 'aggressive Islamic invasion' - are thought to become a new religiously framed in-group. Forlenza (2019: 135) for example assumes that 'references to religion and to the defence of Europe as a Christian civilisation have become increasingly central in the narrative of European right-wing populism in the last 10-15 years, and more evidently in the last few years'. Yet, it is important to emphasise that Christian references of RRP are 'a precipitate of their civilizational preoccupation with Islam' (Brubaker, 2017: 1200) and do not derive from a religious background of these actors. The radical right appeals to Christian and European values 'as a means to justify even more restrictive measures to the detriment of [Muslim] immigrants' (Rosenberger and Hadj-Abdou, 2013: 160).

The same is true for pro-secular messages adopted by the radical right in recent years, which are 'driven by the preoccupation with Islam' (Brubaker, 2017: 1201) and not triggered by the original liberal concern about the church's influence on society and the state. While anti-clerical movements traditionally mobilised against the power of the church, secular arguments from the radical right build on a slightly different logic. Despite the fact that Islam and Muslim communities have little institutional and political power in Western Europe, the radical right increasingly portrays Islam as a threat to secular society and liberal values while taking the major influence of the Christian church out of sight. The main accusation in this regard is 'that Islam knows of no "separation between State and Church"" (Bader, 2007: 47) while Christianity is seen as a cause for the secular nature of societies rather than as an obstacle: "If "they" are religious (in suspect ways) because they are Muslim, "we" are secular because we are (post-) Christian' (Brubaker, 2017: 1200).

It is important to stress that religious references of the radical right derive from the nativist ideology and not from a populist orientation. It seems to become academically fashionable to link different political phenomena to populism. In many cases, this appears reasonable but regarding religious discourses, this is rather misleading. Different scholars talk about 'populism and religion' and explain religious discourses of the radical right - explicitly or implicitly - by their alleged populist nature (Arato and Cohen, 2017; DeHanas and Shterin, 2018; Forlenza, 2019; Zúquete, 2017). We argue that populism - defined as a thin ideology (Mudde 2004) - has nothing to do with 'religious' references. Populism divides society solely in a vertical dimension juxtaposing the political elite with the people. The exclusion of Muslims as a religious out-group - which provides the discursive fundament for proChristian and secular statements - is due to the nativist ideology of the far-right, which creates in- and outgroups in a horizontal dimension (Mudde, 2007).

But what do we know empirically about religious communication in party politics? So far, there are few longitudinal studies addressing the question if religious communication is on the rise in Western European party systems. Mattes (2018) measures references to Islam and Muslims within parliamentary debates in Austria, Switzerland and Germany between 1993 and 2013 stating that Islam became an issue only some years after $9 / 11$. Yet, while focusing on messages directed towards Islam, she does not measure references to secularism or Christianity. The latter is done by a recent comparative study, which analyses Facebook posts and election manifestos of political parties in seven Western European countries (Schwörer and Romero-Vidal, 2020). Conducting a quantitative content analysis, the findings suggest that RRP indeed refer more often to Islam (negative) and to Christianity (positive) than any other party type, although pro-Christian messages hardly occur in RRP's discourses. While this study provides a first methodological approach for measures of religious communication and an examination of the salience of pro-Christian and anti-Muslim messages it does not assess how these discourses develop over time. The same is true for case studies or research with a smaller $\mathrm{n}$ (Martino and Papastathis, 2018; Roy, 2016b; Schwörer, 2018).

\section{Hypotheses}

For several scholars, the September 11 terrorist attacks mark a symbolic turning point for the Western European radical right (Brubaker, 2017; Forlenza, 2019; Kallis, 2018). 9/11 did not only affect domestic politics of the United States but in contrast to previous Islamist attacks - such as the 1995 series of attacks in France - created a global atmosphere of fear or speaking with Kallis (2018: 43), 'an atmosphere of heightened insecurity' and an opportunity for the radical right to point 'to an allegedly transnational, indeed global enemy'. Yet, Mattes (2018) argues that Islam was not immediately declared the most important enemy after $9 / 11$, stressing that we should not overemphasise the meaning of this terrorist event. Nevertheless, even her data shows that Islam was no relevant issue in parliamentary debates before $9 / 11$ but only some years afterwards. Certain factors favouring Islamophobic moods increased steadily in the years after the 'initial event' of 9/11. Bleich (2009) as well as Kaya and Tecmen (2019) identify further terrorist attacks conducted by Islamic terrorists in the subsequent years as trigger for the radical right's anti-Muslim discourses. Additionally, the 
accession negotiations with Turkey, which started in 2005, and increasing numbers of Muslim immigrants - reaching their peak during the 'refugee crisis' in 2015 - provided further discursive opportunities for anti-Islam messages (Osiewicz, 2017; Rosenberger and Hadj-Abdou, 2013; Vasilopoulougoop, 2011). Due to these events, which created an increasingly fertile foundation for Islamophobic discourses, we assume that anti-Muslim communication of RRP increases linearly - albeit not immediately - after 9/11. The same should be true for pro-Christianity discourses, which are considered a precipitate of the farright's rejection of Islam (Brubaker 2017; Schwörer and Romero-Vidal, 2020). Thus, the net evaluation of Islam (positive - negative references) should become increasingly negative while the net evaluation of Christianity is expected to develop in a positive direction.

H1a: Anti-Islam messages increase linearly in the 21 st century among RRP.

H1b: Pro-Christian messages increase linearly in the 21st century among RRP.

In addition, we expect that mainstream parties are affected by anti-Muslim messages from the radical right as well. Besides spatial approaches assuming that political parties are responsive to policy shifts of ideologically related rival parties (Adams, 2012; Adams and SomerTopcu, 2009; Budge, 1994), literature on the framing of Islam provide further arguments in this respect. Analysing the portrayal of Muslims in parliamentary debates, Mattes (2018: 197) found 'a great variation in the overall emphasis on security, which is much stronger in the countries with right-wing parties that frequently bring up security issues in immigrant integration policy debates and relate them to the category "Muslim". In a similar vein, Han (2015: 567) found that 'RMPs [right mainstream parties] shift to a more restrictive position on multiculturalism as long as the salience of the issue increases or RRP grow'. Hence, we expect that centre-right mainstream parties - which are ideologically closer to the far-right than the centre-left are 'contaminated' by anti-Islam and pro-Christian messages from RRP. Accordingly, the second hypothesis is as follows:

H2: Centre-right parties adopt pro-Christian and antiMuslim messages when they are becoming salient within RRP's communication.

However, since we do not control for other variables (e.g. levels of non-Christian immigration; shifts in public opinion), we cannot identify clear causal relations in this respect. Yet, the descriptive results will at least provide first arguments for or against the contagion thesis on which future analyses can build on.
But what can be expected regarding secular messages? As mentioned in the previous section, the radical right supports secularism in order to exclude Islam. Cesari (2011: 21) claims that a 'secular anti-Islamic discourse' intensified after the 9/11 attacks (see also: Brubaker 2017). However, some RRP also refer to anti-secular arguments arguing that Christian values should be present in public life. Schwörer (2018), for example, identified rather anti-secular discourses within political texts of the Italian Northern League rejecting 'gender ideology' due to its supposed incompatibility with Christian values. Similar observations have been made for other RRP such as the Spanish Vox (Schwörer et al, 2020). Yet, following a rather paradoxical argumentation (Pickel, 2013), the same parties criticise Islam of not accepting secular values in order to justify its exclusion from the native society. Thus, we do not think that the net-evaluation of secularism is becoming linearly more positive. What we expect is that pro- as well as anti-secular messages are increasingly used by the radical right in the 21 st century due to the discovery of Muslim out- and Christian in-groups.

H3. The saliency of secular messages from RRP (pro as well as anti-secular statements) increases linearly in the 21 st century.

Last, there might be a further dimension not explicitly mentioned by some scholars (Brubaker, 2017; Minkenberg, 2018). We argue that the rejection of peaceful Islam implies a critical stance towards the principle of religious freedom, which is guaranteed by law in Western European countries. The rejection of minarets for example - a common stance of the Western radical right - has 'very little to do with religious freedom' (Kallis, 2018: 50). In his chapter about the radical right and Islamophobia, Kallis (2018: 49ff) describes the starting points for radical right discourses rejecting religious symbols and diversity in countries such as Austria, Switzerland and Italy. All the examples he mentions fall in the 21st century. As mentioned above, religious and cultural diversity is rejected by right-wing radicals because of their nativist ideology (Mudde, 2007), which sees the foreign as a threat to the own nation. The foreign might not only be Islam but also other religious minorities. Yet, since Islam became the most relevant out-group, we assume that sceptical discourses about diversity and religious freedom grow linearly in the 21 st century.

H4: Messages questioning religious diversity and freedom increase linearly among RRP in the 21 st century.

\section{Research design and method}

In order to answer the question whether religious messages gained salience in party politics, we focus on Western 
European party systems where references to Christian inand Muslim out-groups as well as references to secularism are mostly expected (Brubaker, 2017; Minkenberg, 2018). Moreover, our content-analytical approach requires a good knowledge of the languages in which the texts are produced. This is why we do not include countries from Scandinavia into the case selection. The longitudinal design further requires party systems where RRP existed before the 2000s. In order to select them, we rely on the specialised literature on the topic. To ensure that the selected parties present the main characteristic of the radical right, namely nativism, we reviewed their positions on immigration, nationalism and their overall left-right positions referring to data from the Chapel Hill Expert survey. As shown in the appendix (A1), this is the case for the French National Rally (RN) - formerly known as National Front - the Freedom Party of Austria (FPÖ), the Swiss People's Party (SVP), the United Kingdom Independence Party (UKIP) and the Italian League - formerly known as Northern League (LN). RN and FPÖ are considered the prototype cases of the populist radical right (Mudde, 2007). Regarding the latter, the populist radical right takeover took place in 1986, when Haider was elected as the leader of the party (Mudde, 2007). The SVP started as a rural conservative centre-right party and became a radicalised political actor in the 1990s, putting great emphasis on immigration and the question of Swiss identity under the guidance of Christoph Blocher (Mazzoleni and Skenderovic, 2007). The characterisation of UKIP - officially founded in 1993 as RRP is more contested within academia. The seminal work of Cas Mudde (2007) did not classified it as RRP. However, other authors argue that 'UKIP can and should be understood as falling within the European populist radical right' (Hayton, 2016: 402). Also Rooduijn et al. (2019) describe UKIP - as well as the RN, FPÖ and SVP - as a party from the radical right. Moreover, the UKIP's rightwing orientation can hardly be considered a novelty: Still before its electoral breakthrough, it 'has put a particularly strong emphasis on its opposition to immigration, multiculturalism and Islam' (Ford et al., 2012: 209). The Northern League emerged from various autonomist movements in 1991 during the collapse of the Italian party system. While scholars agree that the party can be characterised as nativist since Salvini took over the party (Albertazzi et al., 2018, A1), Mudde is sceptical about Bossi's nativist orientation (2007: 56) but still claims that the LN under Bossi is too similar to be excluded from the RRP family. Also Bulli and Tronconi (2011: 53) argue, that the LN rejected immigration from non-European countries already in its autonomist phase.

We examine religiously framed discourses focusing on national election manifestos of radical right and centre-left as well as centre-right parties in France, the United Kingdom, Austria, Switzerland and Italy. Party manifestos are considered as comparable statements of parties offering a univocal agenda (Hansen, 2008; Manucci and Weber, 2017). We collect the manifestos from the 'Manifesto Project' ${ }^{2}$ and - if programs were not available - from 'The Political Documents Archive ${ }^{3}$. In order to know how religious references developed in the last decades and whether the turn of the century represents a turning point for the radical right, we select one election period in the (late) 1980 s, one from the 1990s and three elections after $9 / 11$. Focusing on three periods in the 21 st century allows to observe whether religious references increase linearly as expected by the hypotheses - or rather randomly. In total, we analyse 71 election manifestos (Appendix 2).

The manifestos were analysed using a combination of computer-based and classical quantitative content analysis (Rooduijn and Pauwels, 2011) selecting the single sentence as unit of measurement. In a first step, we created a comprehensive dictionary including keywords that might refer to Christianity, Islam, secularism or religion in general. We built on existing dictionaries in this regard (Schwörer and Romero-Vidal, 2020) and included further terms based on theoretical reflections and preliminary tests (Appendix 3). After running the analysis, we manually analysed every sentence in which a keyword from the dictionary appeared in order to trace its concrete meaning. In sum, we assess whether Islam/Muslims, Christianity/Christians, secularism and religious freedom/diversity is portrayed in a positive or negative way (for more details on how we operationalise the religious dimensions see Appendix 4). ${ }^{4}$

For the sake of inter-coder reliability, we calculated Cohen's Kappa. Therefore, the British election manifestos - which were coded by the second author - were coded by author one according to the same codebook and categories. Table 1 mentions the coefficients for Cohen's Kappa for all relevant categories. In order to assess the inter-coder consistency, all coded sentences of a respective category in British manifestos were coded by author one as well as the same amount of sentences (random sampling) which contain a religious keyword but which were not coded according to the respective category. Few categories hardly occur in the text (e.g. pro Christianity) and respective indices should not be overemphasised. Yet, since Cohen's Kappa is always above 0.8 and mostly statistically significant, inter-coder reliability can be seen as almost perfectly consistent (Landis and Koch, 1977).

\section{Analysis}

First, we start with the salience of religious references in general. Figure 1 illustrates the percentage of religious references - be it references to Islam, Christianity, secularism or any other religious dimension - in Western European parties' manifestos between 1986 and 2018. Before 2002-2005, religion is not a salient issue for any of the three mentioned party families. Only since 2007-2010 the amount of religious elements increases significantly among 
Table I. Inter-coder reliability scores according to Cohen's Kappa.

\begin{tabular}{|c|c|c|}
\hline Category & Operationalisation & Cohen's Kappa \\
\hline Pro Christianity & $\begin{array}{l}\text { Attribution of positive actions, behaviour/positive characteristics, values; Actor is made } \\
\text { responsible for a positive development or situation } \\
\text { Religion/religious group is portrayed as victim; unfairly or badly treated } \\
\text { Speaker is in favour of supporting religion/religious group or illustrates the religion's } \\
\text { importance } \\
\text { Speaker claims to belong to religion/religious group, to know its need or to act in its } \\
\text { interest }\end{array}$ & $1.000(n=8)$ \\
\hline Pro Islam & See above & $1.000 *(n=6)$ \\
\hline Against radical Islam & $\begin{array}{l}\text { Attribution of negative actions, behaviour/negative characteristics, values; actor is made } \\
\text { responsible for a negative development or situation } \\
\text { Religious group is portrayed as preferentially treated; too powerful } \\
\text { Denying rights or privileges and questions positive contributions of a religious group and } \\
\text { its belonging to society } \\
\text { Describing alleged consequences of accepting religious groups, such as terror, lack of } \\
\text { security or negative financial situations }\end{array}$ & $1.000 * * *(n=32)$ \\
\hline Against moderate Islam & See above & $0.857 * * *(n=14)$ \\
\hline Pro secularism & $\begin{array}{l}\text { Supporting secular principles/against the implementation of religious principles in treaties, } \\
\text { law, public institutions }\end{array}$ & $0.867^{* * *}(\mathrm{n}=30)$ \\
\hline Against secularism & $\begin{array}{l}\text { Against supporting secular principles/in favour of the implementation of religious } \\
\text { principles in treaties, law, public institutions }\end{array}$ & $1.000 * *(n=8)$ \\
\hline $\begin{array}{l}\text { Pro religious freedom/ } \\
\text { diversity }\end{array}$ & $\begin{array}{l}\text { Supporting religious diversity; accepting single religions; speaks out against groups or } \\
\text { regimes not accepting freedom of religion } \\
\text { Supporting groups which are explicitly named 'religious/faith minorities' } \\
\text { Defending explicitly freedom of religion }\end{array}$ & $0.917 * * *(n=24)$ \\
\hline $\begin{array}{l}\text { Against religious } \\
\text { freedom/diversity }\end{array}$ & $\begin{array}{l}\text { Openly rejecting the coexistence of different religious groups or the principle of freedom } \\
\text { of religion } \\
\text { Arguing that certain behaviours or norms are not covered by freedom of religion } \\
\text { Criticising a (non-radical) religions' practices, privileges, rights or symbols; emphasising } \\
\text { that religions should behave according to native values and law (or that religions should } \\
\text { be controlled); demanding less tolerance towards (moderate) religious groups; } \\
\text { opposing native values with those from religious groups }\end{array}$ & $0.857 * * *(n=28)$ \\
\hline
\end{tabular}

Note: $* * * \mathrm{p}<0.001,{ }^{*} \mathrm{p}<0.01,{ }^{*} \mathrm{p}<0.05$

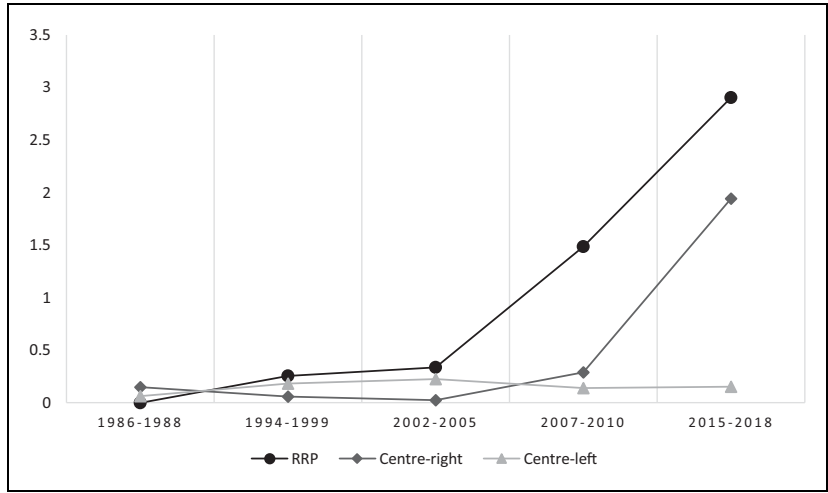

Figure I. Religious references in Western European parties' manifestos.

RRP's manifestos (until reaching $2.9 \%$ on average in 2015-2018; SD = 1.37) and since 2015-2018 in centreright parties' programs $(1.94 \% \text { on average; } \mathrm{SD}=2.72)^{5}$. Centre-left parties only slightly increase the amount of religious messages after $9 / 11(0.15 \%$ on average in 2015 2018; $\mathrm{SD}=0.2$ ). In sum, the results suggest that religion has indeed become a more salient issue after the turn of the century, especially among the radical and to a lower extent among the centre-right. Yet, religious references do not increase immediately after $9 / 11$, but only some years later (starting from 2007). Appendix 5 provides findings for the single parties of each party family and suggests that despite a considerable standard deviation - the trend can be observed among all countries under examination.

Moving on to Hypothesis 1a - the radical right becomes increasingly hostile towards Islam in its election manifestos after the turn of the century - Figure 2 shows the net evaluation of Islam among RRP over time. It should be noted that these percentages include all kind of mentions of Islam also the rejection of fundamentalist Islam. Yet, regarding the net evaluation of moderate Islam the trend is very similar with the exception of the RN (see Appendix 6). ${ }^{6}$ The analysis reveals that the far-right's anti-Islam messages increase linearly since the beginning of the 21 st century 


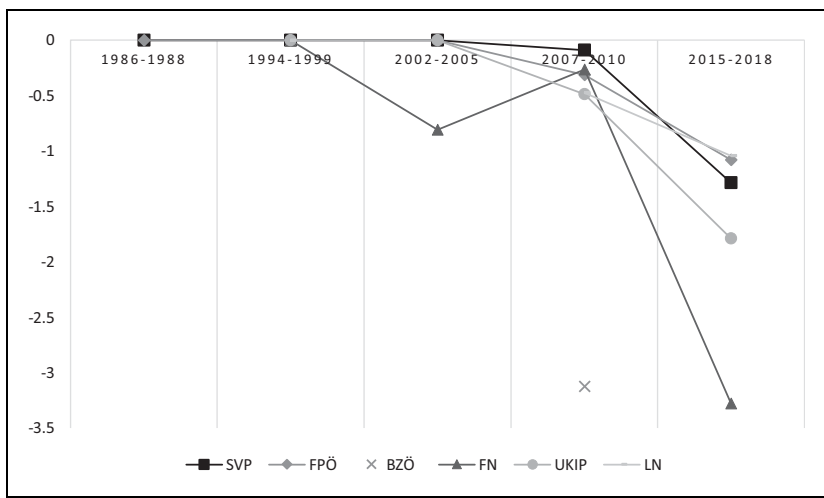

Figure 2. Net evaluation of Islam in RRP's manifestos.

supporting Hypothesis 1a. There are no negative references to Islam in election manifestos from the 1980s and 1990s. Interestingly, most RRP introduce negative references to Islam not immediately after $9 / 11$ but rather in the period 2007-2010 and more frequently in 2015-2018. Only the French National Front under Jean-Marie Le Pen already rejected Islam in 2002 (but less so in 2007). As Bowen (2009) points out, debates about Islam started early in France and Islamist terrorist attacks threatened the country already in the mid-1990s, which could explain why the French radical right adopted negative references to Muslims particularly early. Between 2007 and 2010 the Austrian BZÖ displays the most negative score towards Islam $(-3.13)$. The Austrian results are in line with the argument made by Rosenberger and Hadj-Abdou (2013) that Islam became a dominant issue for the Austrian radical right only after 2005, when parts of the FPÖ left the party founding the $\mathrm{BZO}$ and the radical right went back into opposition. This period also includes the manifestos for the first elections held after the Islamist attacks in London in July $2005^{7}$ as well as the start of negotiations for Turkey's accession to the EU offering further discursive opportunities for antiIslam campaigns. Yet, after 2010, negative references to Islam rise even more significantly in RRP's manifestos $(-1.7$ on average; $\mathrm{SD}=0.93)$. Among all RRP it is the $\mathrm{RN}$ increasing its share of negative references to Islam and Muslims in the most considerable way (-3.28 in 2017). This might partially be due to the terrorist attacks France experienced between 2015 and 2016 shortly before the respective elections. Likewise, the values obtained in the latest manifestos might reflect the perceived threat of the so-called refugee crises and the growing flows of immigration from Muslim countries. Appendix 7 illustrates the results for the single countries.

While we found clear support that the radical right linearly increases its anti-Islam messages since the turn of the millennium, we cannot clearly confirm that for proChristian messages (H1b). Figure 3 shows the development of Christianity's net evaluation over time. First, it seems to be true that parties are more prone to evaluate Christianity

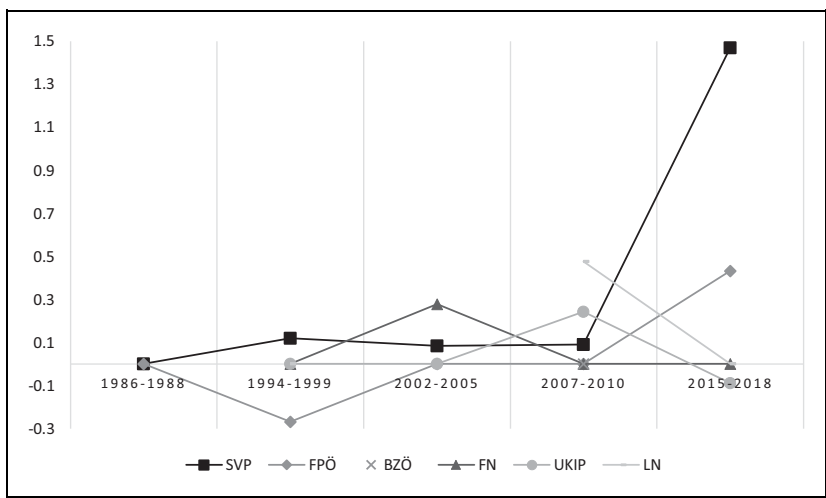

Figure 3. Net evaluation of Christianity in RRP's manifestos.

in a positive way in the 21 st century. Before 2001, only the SVP shows a slightly positive net evaluation towards Christianity (0.12 in 1999). While RN and UKIP do not use any type of Christian messages prior to the 2000s, the FPÖ even evaluates Christianity in a rather negative way in 1994 $(-0.27)$. After the turn of the century, all parties from the far-right evaluate Christianity in a rather positive way at least in one of their manifestos. RN is doing to in 2002, UKIP in 2010, LN in 2008 and SVP (2015) and FPÖ (2017) in the 2015-2018 period. However, we do not find a linear cross-national trend in recent years. The far-right in Austria and Switzerland implement pro-Christian messages in their current manifestos while RN in France and UKIP stopped using such references recently. Accordingly, the amount and relevance of pro-Christian messages might depend on more country-specific factors. Especially the SVP in Switzerland strongly emphasises pro-Christian discourses. However, compared to the salience of anti-Islam messages illustrated in Figure 2, references to Christianity do not seem to be a very important discursive element of the radical-right what might explain their sporadic use. The scores for pro-Christian messages are much lower than for anti-Islam statements (again, except the SVP). Appendix 8 shows the findings for the single countries.

Figure 4 illustrates the net evaluations of Islam and Christianity of RRP and centre-right parties. We find some support for Hypothesis 2, although only partially: Centreright parties adopt anti-Muslim and pro-Christian messages when they are becoming salient within RRP's communication. Indeed, all centre-right parties of the sample, with the exception of the CVP and FI (in the case of the FI the 2018 manifesto only counts 86 sentences), include negative references to Islam in 2015-2018 ( $\mathrm{M}=-1.17$; SD = 1.28). Yet, the centre-right does not adopt anti-Islam messages in 2007-2010. Especially in Austria this is surprising and not totally in line with our hypothesis: In 2008, the BZÖ - and to a lower extent also the FPÖ - emphasised negative aspects of Islam to a very considerable extent but we did not find any negative reference towards Islam in 


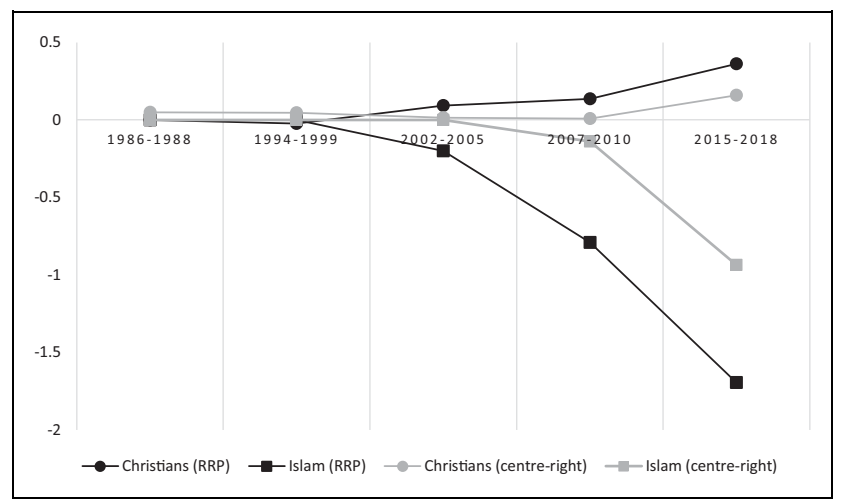

Figure 4. Net evaluations of Islam and Christianity in RRP's and centre-right parties' manifestos.

centre-right's manifestos until 2017 (Appendix 7). Hence, pressure from the radical right might not be a sufficient incentive for all centre-right parties and the fact that the latter adopt anti-Islam messages after 2015 could also be explained by the influx of Muslim immigrants during the so called 'refugee crisis'. Regarding a supposed contagion effect of pro-Christianity messages, we are confronted with even less conclusive results given the low number of references found in centre-right parties' manifestos. Nevertheless, at least the Austrian and Swiss centre-right - and to a lower extent the British Conservatives - adopt proChristian messages in the 2015-2018 period. Regarding the ÖVP and Conservatives, these discourses are accompanied by negative references to Islam, suggesting that also the centre-right's communication partly follows an in- and outgroup logic. At this point, we argue that the centreright's references to Christianity strongly depend on country specific factors. Within our sample of centreright parties, the Christian Democratic ÖVP and CVP are mostly the only ones referring to Christianity. The existence of Christian Democratic parties (and their references to Christianity) is a result of the traditional religious cleavage that has been particularly intense in countries such as Switzerland, Austria and Germany (Knutsen, 2004: 98). To strengthen the assumption that country specific cleavage structures and resulting Christian parties account for proChristianity discourses, we further coded manifestos from German parties - including the Christian Democratic Union parties - revealing a strong focus on pro-Christian messages (Appendix 8).

We proceed with Hypothesis 3 . According to academics, RRP increasingly refer to pro-secular discourses in order to exclude Islam from secular Europe or adopt rather antisecular messages in order to emphasise Christian values. Accordingly, we think that secularism as an issue is linearly gaining salience after the turn of the century but that there is no consistent trend of evaluating it in a positive or negative way. Figure 5 illustrates the salience of secular messages in RRP's manifestos regardless of the type of

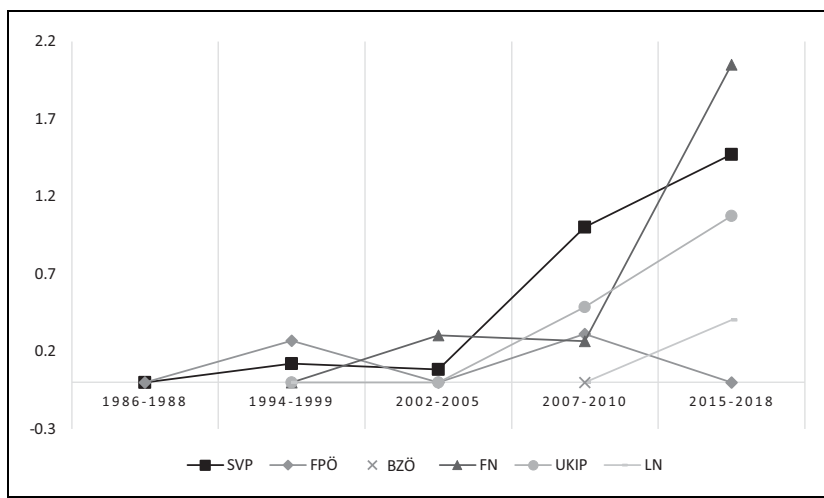

Figure 5. Salience of pro and anti-secular messages in RRP's manifestos.

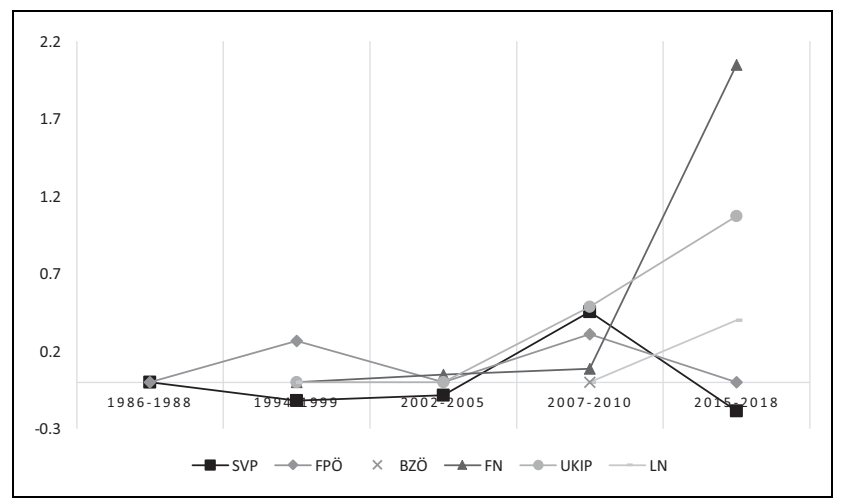

Figure 6. Net evaluation of secularism in RRP's manifestos.

evaluation. The analysis reveals a mostly linear trend: SVP, $\mathrm{RN}$, UKIP and LN increase secular discourses between 2007 and 2018. Accordingly, Hypothesis 3 can rather be confirmed - only the FPÖ does not use secular references in 2015-2018. Additionally, Figure 6 illustrates how secularism is evaluated by the far-right suggesting that most mentions are positive ones. Especially the French RN evaluates secularism in a very positive way, which can be explained by the strong role of the French 'laïcité' within the constitution order and in actual political life leading parties to avoid religious discourses (Müller, 2003). Only among the SVP, a slightly negative discourse dominates (except in 2010) what can be explained by its strong emphasis on positive references to Christianity (e.g. 1.47 in 2015).

In this regard, we wonder whether there is a link between the evaluation of Christianity and Islam on the one hand and discourse about secularism on the other. Do pro-secular messages appear in those manifestos, which reject Islam particularly often? And is there a connection between pro-Christian messages and negative discourses about secularism? Figures 7 and 8 provide support for these assumptions illustrating respective data for each manifesto under examination. They show a statistically significant 


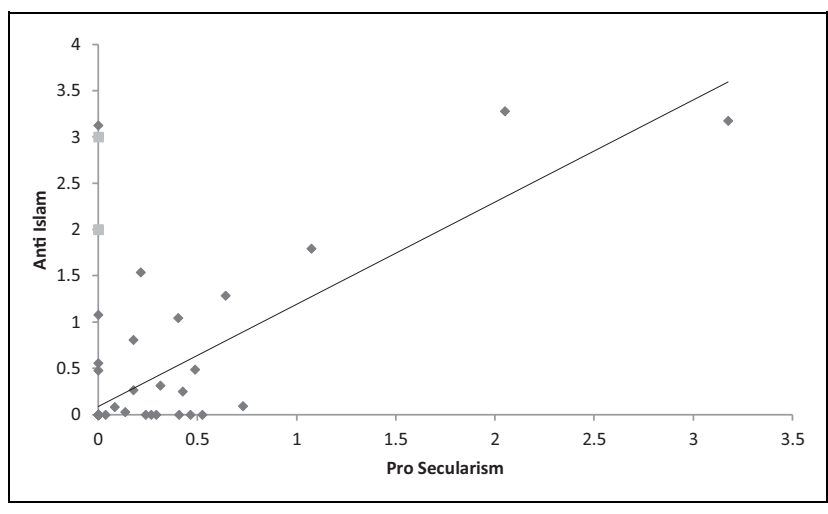

Figure 7. Correlation between anti-Islam statements and prosecularism in party manifestos.

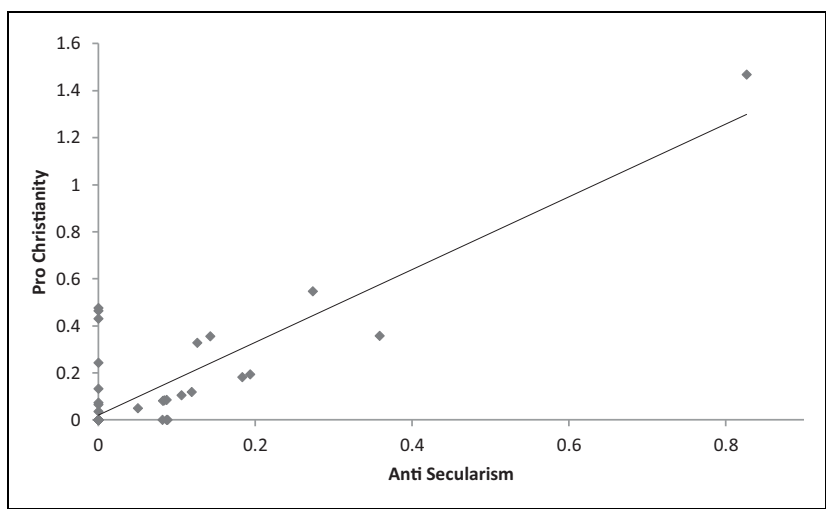

Figure 8. Correlation between pro-Christian statements and anti-secularism in party manifestos.

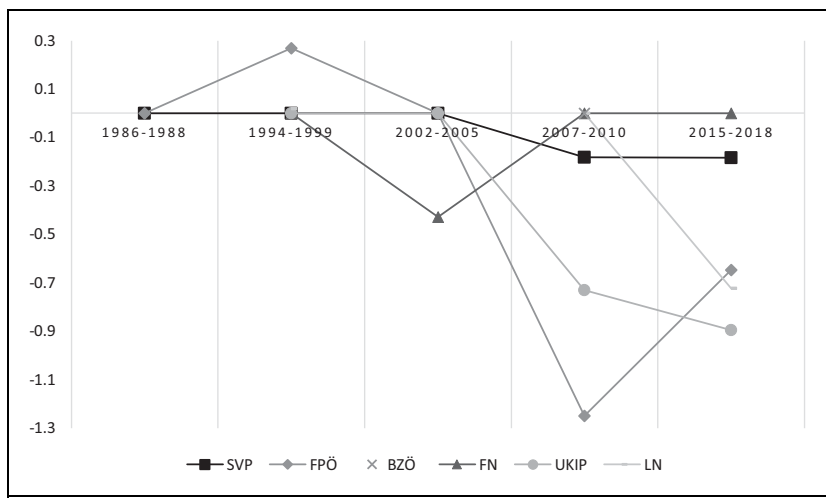

Figure 9. Net evaluation of freedom of religion in RRP's manifestos.

correlation between anti-Islam messages and pro-secular discourses in election manifestos $(r=.732 ; \mathrm{p}<0.001)$ while positive evaluations of Christianity are strongly correlated with negative positions towards secularism $(\mathrm{r}=.845 ; \mathrm{p}<0.001)$. The same is also true if we only consider RRP's manifestos (Islam vs. secularism: $r=$ .644; $\mathrm{p}<0.001$; Christianity vs. secularism: $\mathrm{r}=.897 ; \mathrm{p}<$ $0.001)$.

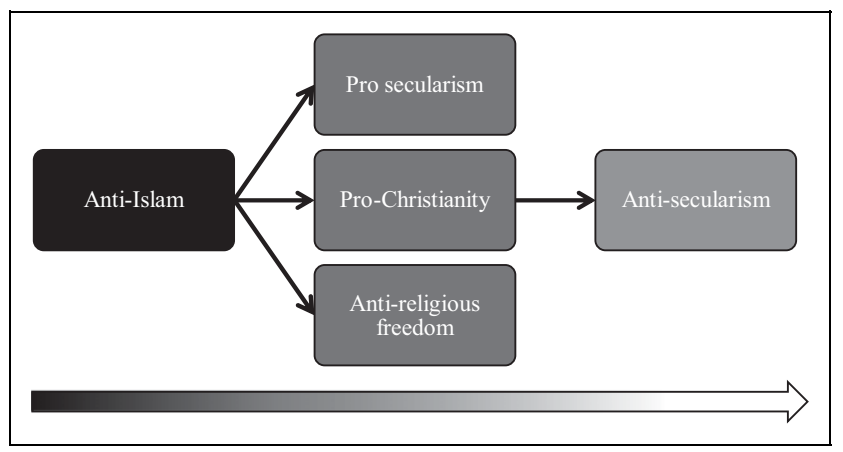

Figure 10. Origins of radical right parties' religious discourses. Note: Arrows symbolise the origin of religious references from left to right (e.g., pro secular messages derive from the anti-Islam orientation). Decreasing darkness of the gradient represents a decline in the salience.

While we can confirm assumptions about anti-Islam and secular discourses of the radical right (but only partially about pro-Christianity messages), we now move on with the last hypothesis (4). Figure 9 illustrates how religious freedom is evaluated over time by the radical right and reveals that - with the exception of the French RN - RRP reject it especially since 2007. Yet, while Islam is becoming steadily more negatively evaluated in the 2000 s, such a linear trend cannot be observed here. Hence, we cannot fully confirm Hypothesis 4 . The findings further suggest a link between anti-Islam and anti-religious freedom discourses. In the 20th century, when Muslims are no target of the far-right's rhetorical attacks, religious diversity is not questioned. Only those manifestos with a negative netevaluation of Islam criticise religious diversity and the principle of religious freedom. This is true for nearly all manifestos after the turn of the century (only RN's manifestos from 2007 and 2017 - which criticise radical but not moderate Islam - do not question religious freedom).

\section{Discussion and conclusion}

Several scholars claim that religion is on the rise in party politics. RRP are expected to refer increasingly to religiously framed in- (Christians) and outgroups (Muslims) in the 21st century. Moreover, it is argued that the farright refers to secular arguments in order to exclude 'nonsecularised' Islam from Western societies and questions religious freedom and diversity. In this respect, we provided a first comparative and longitudinal analysis of religious dimensions in party manifestos. The findings of our quantitative content analysis mostly support the assumptions from the academic literature. Recently - between 2007 and 2018 - the radical right is increasingly engaged in anti-Islam and pro-Christian discourses, which also means that 9/11 did not affect radical right's discourses immediately. Yet, excluding Muslims seems to be a much more salient communicative content for the radical right 
than praising Christianity. Moreover, the negative evaluations of Muslims increase steadily and linearly within the first two decades of the 21 st century while pro-Christian discourses do not follow a clear linear trend. RRP further include discourses about secularism much more often again, not immediately after $9 / 11$ but rather since 2007 . They mostly support secular arguments which, however, seem to derive from their anti-Islam orientation: Prosecular messages are mostly accompanied by discourses against Muslims. Thus, in accordance with Brubaker (2017), we argue that the religious dimensions addressed by the radical right derive from its anti-Islam orientation. Anti-Islam messages lead to positive references to secularism and Christianity. Yet, positive references to Christianity seem to produce rather negative framings of secularism, for example, when Christian values are praised and portrayed as guidelines for public life and political agendas. In this regard, the radical right refers to a 'remarkable mixing argument' (Pickel, 2013) and uses secular arguments as a tool to exclude religious out-groups but rejects secularism in order to appeal to religiously framed in-groups. In addition, besides anti-Islam, pro-secular and pro-Christian messages, we found that critical statements towards the principle of religious freedom and diversity increase after the turn of the century. In this respect, we further assume a link between anti-Islam and anti-religious freedom discourses: Religious freedom and diversity is only criticised in those manifestos, which also reject Islam. Figure 10 illustrates the assumed origin of radical right's religious communication.

What are the consequences of these discourses? Our study further illustrated that not only the radical right, but also centre-right mainstream parties increasingly criticise radical Islam in the new millennium and refer slightly more often to Christianity as a native in-group. However, we do not think that this occurred only due to pressure from the radical right, but also due to the 'refugee crisis' (and shifts in public opinion) since the centre-right adopts anti-Islam messages mostly since 2015 . Additionally, only few mainstream parties attack moderate Islam but mostly the fundamentalist branch. Notwithstanding, if the far-right remains electorally successful framing religious groups as nonnative others, a rejection of moderate Islam could also play a bigger role for the political mainstream in future elections (the French and Austrian centre-right already implemented discourses against non-radical Islam). Thus, it is not said that the rejection of moderate Islam remains on the fringe of the political spectrum for all times.

Concluding, religious discourses constitute an important discursive element of the far-right nowadays. While the traditional conflict between church and state does not dominate party competition any more, we experience the evolution of a new religious cleavage originating from the exclusion of Muslims. Whether this new cleavage is moving towards more secularisation (Islam as a threat to secular Europe) or more religious polarisation (Islam as a threat to Christian Europe) is difficult to determine yet. We rather see a combination of both divisions and considerable country-specific developments. Where Christian Democratic parties continue to be successful, the radical right seems more inclined to represent Islam as a threat to the Christian roots of their countries (Switzerland and Austria). In France, the UK and Italy - lacking successful Christian Democratic parties - the radical right recently appears to lean more towards secular arguments, especially in France (Figure 6 and Appendix 6). However, in general, we should not overemphasise the religious dimensions of RRP's discourses since they mostly emphasise on Islam. References to Christianity, secularism or religious diversity play a subordinate role. Hence, other non-religious in-groups and values might be addressed more frequently, such as nationally framed people and values.

\section{Declaration of conflicting interests}

The author(s) declared no potential conflicts of interest with respect to the research, authorship, and/or publication of this article.

\section{Funding}

The author(s) received no financial support for the research, authorship, and/or publication of this article.

\section{ORCID iD}

Jakob Schwörer (D) https://orcid.org/0000-0001-9081-4849

\section{Supplemental material}

Supplemental material for this article is available online.

\section{Notes}

1. Other scholars prefer the term ethnic nationalism (Rydgren, 2017). Yet, the concept of ethnic nationalism does not differ substantially from nativism (Pauwels, 2014: 25).

2. URL: https://manifesto-project.wzb.eu/.

3. URL: http://www.polidoc.net/.

4. The codebook is available on request.

5. The high standard deviation is primarily caused by the French Republicans, which obtain a percentage of $6.35 \%$, much higher than other centre-right parties varying between $0 \%$ and $2.75 \%$.

6. In general, fundamentalist Islam is more often rejected than moderate Islam. Yet, the findings show that the radical right also criticises moderate Islam unlike most centre-right manifestos (except ÖVP in 2017 and UMP in 2007).

7. The 2005 elections in the United Kingdom (included in the previous period) were held in May, two months before the terrorist attacks.

\section{References}

Adams J (2012) Causes and electoral consequences of party policy shifts in multiparty elections: theoretical results and 
empirical evidence. Annual Review of Political Science 15(1): 401-419.

Adams J and Somer-Topcu Z (2009) Policy adjustment by parties in response to rival parties' policy shifts: spatial theory and the dynamics of party competition in twenty-five postwar democracies. British Journal of Political Science 39(4): 825-846.

Albertazzi D, Giovannini A and Seddone A (2018) 'No regionalism please, we are Leghisti!' the transformation of the Italian Lega Nord under the leadership of Matteo Salvini. Regional \& Federal Studies 28(5): 645-671.

Arato A and Cohen JL (2017) Civil society, populism and religion. Constellations 24(3): 283-295.

Bader VM (2007) Secularism or Democracy? Associational Governance of Religious Diversity. Amsterdam: Amsterdam University Press.

Bar-on T (2018) The radical right and nationalism. In: Rydgren J (ed.) The Oxford Handbook of the Radical Right. Vol. 1: Oxford: Oxford University Press, pp. 17-41.

Bleich E (2009) Muslims and the state in the post-9/11 West: introduction. Journal of Ethnic and Migration Studies 35(3): 353-360.

Bowen JR (2009) Recognising Islam in France after 9/11. Journal of Ethnic and Migration Studies 35(3): 439-452.

Brubaker R (2017) Between nationalism and civilizationism: the European populist moment in comparative perspective. Ethnic and Racial Studies 40(8): 1191-11226.

Budge I (1994) A new spatial theory of party competition: uncertainty, ideology and policy equilibria viewed comparatively and temporally. British Journal of Political Science 24(4): 443-467.

Bulli G and Tronconi F (2011) The Lega Nord. In: Anwen E and Tronconi F (eds) From Protest to Power. Autonomist Parties and the Challenges of Representation. Wien: Braumüller, pp. $51-74$.

Cesari J (2011) Islamophobia in the West: a comparison between Europe and the United States. In: Esposito JL and Kalin I (eds) Islamophobia: The Challenge of Pluralism in the 21st Century, Oxford: Oxford university press, pp. 21-43.

DeHanas DN and Shterin M (2018) Religion and the rise of populism. Religion, State and Society 46(3): 177-185.

Ford R, Goodwin MJ and Cutts D (2012) Strategic Eurosceptics and polite xenophobes: support for the United Kingdom Independence Party (UKIP) in the 2009 European parliament elections. European Journal of Political Research 51(2): 204-234.

Forlenza R (2019) Abendland in Christian hands: Religion and populism in contemporary European politics. In: Fitzi G, Mackert J and Turner BS (eds) Populism and the Crisis of Democracy, Vol 3. Routledge Advances in Sociology. London, New York: Routledge Taylor \& Francis Group, pp. 133149.

Han KJ (2015) The impact of radical right-wing parties on the positions of mainstream parties regarding multiculturalism. West European Politics 38(3): 557-576.
Hansen ME (2008) Back to the archives? A critique of the Danish part of the manifesto dataset. Scandinavian Political Studies 31(2): 201-216.

Hayton R (2016) The UK independence party and the politics of Englishness. Political Studies Review 14(3): 400-410.

Kallis R (2018) The radical right and islamophobia. In: Rydgren J (ed.) The Oxford Handbook of the Radical Right, Vol. 1. Oxford: Oxford University Press, pp. 42-60.

Kalyvas SN and Van Kersbergen N (2010) Christian democracy. Annual Review of Political Science 13: 183-209.

Kaya A and Tecmen A (2019) Europe versus Islam? Right-wing populist discourse and the construction of a civilizational identity. The Review of Faith \& International Affairs 17(1): 49-64.

Knutsen O (2004) Religious denomination and party choice in western Europe: a comparative longitudinal study from eight countries 1970-97. International Political Science Review 25(1): 97-128.

Landis JR and Koch GG (1977) The measurement of observer agreement for categorical data. Biometrics 33(1): 159-174.

Lewis P, Clarke S, Barr C, et al. (2018) Revealed: one in four Europeans vote populist: exclusive research shows how populists tripled their vote over the past two decades. The Guardian, 20 November. Avilable at: https:/www.theguardian.com/ world/ng-interactive/2018/nov/20/revealed-one-in-four-eur opeans-vote-populist (accessed 12 March 2019).

Lipset SM and Rokkan S (1967) Cleavage structure, party systems, and voter alignments: an introduction. In: Lipset SM and Rokkan S (eds) Party Systems and Voter Alignments. New York: Free Press, pp. 1-64.

Manucci L and Weber E (2017) Why The big picture matters: political and media populism in western Europe since the 1970s. Swiss Political Science Review 55(2): 1-22.

Martino MG and Papastathis K (2018) The radical right and religious discourse: the independent Greeks, the Lega Nord and the Sweden democrats compared. In: Zapf H, Hidalgo O and Hildmann PW (eds) Das Narrativ von der Wiederkehr der Religion. Politik und Religion. Wiesbaden: Springer VS, pp. 261-287.

Mattes A (2018) How religion came into play: 'Muslim' as a category of practice in immigrant integration debates. Religion, State and Society 46(3): 186-205.

Mazzoleni O and Skenderovic D (2007) The rise and impact of the swiss people's party: challenging the rules of governance in Switzerland. In: Delwit P and Poirier P (eds) The New RightWing Parties and Power in Europe. Brussels: Editions de l'Université de Bruxelles, pp. 85-116.

Minkenberg M (2018) Religion and the radical right. In: Rydgren J (ed.) The Oxford Handbook of the Radical Right, Vol. 1. Oxford: Oxford University Press, pp. 366-393.

Moodod T (2010) Moderate secularism, religion as identity and respect for religion. The Political Quarterly 81(1): 4-14.

Mudde C (2004) The populist Zeitgeist. Government and Opposition 39(4): 541-563.

Mudde C (2007) Populist Radical Right Parties in Europe. Cambridge: Cambridge University Press. 
Müller A (2003) Wie laizistisch ist Frankreich wirklich? Von der kämpferischen zur offenen Laizität. In: Brocker M, Behr H, and Hildebrandt M (eds) Religion - Staat - Politik. Wiesbaden: VS Verlag für Sozialwissenschaften, pp. 69-82.

Osiewicz P (2017) Europe's Islamophobia and the refugee crisis. Middle East Institute, 19 September. Available at: https:// www.mei.edu/publications/europes-islamophobia-and-refu gee-crisis (accessed 5 May 2020.

Ozzano L (2019) Religion, cleavages, and right-wing populist parties: the Italian case. The Review of Faith \& International Affairs 17(1): 65-77.

Pauwels T (2014) Populism in Western Europe: Comparing Belgium, Germany and the Netherlands. Abingdon: Routledge.

Pickel G (2013) Religiosität in Europa und die politische Unterstützung der europäischen integration - ein bezugloses nebeneinander? In: Werkner I-J and Liedhegener A (eds) Europäische Religionspolitik: ReligiöseIdentitätsbezüge, Rechtliche Regelungen und Politische Ausgestaltung. Wiesbaden: Springer, pp. 53-82.

Rooduijn M and Pauwels T (2011) Measuring populism: comparing two methods of content analysis. West European Politics 34(6): 1272-1283.

Rooduijn M, Van Kessel S, Froio C, et al. (2019) The PopuList: An Overview of Populist, Far Right, Far Left and Eurosceptic Parties in Europe.

Rosenberger S and Hadj-Abdou L (2013) Anti-Islamic mobilization of the extreme right in Austria. In: Mammone A, Godin E and Jenkins B (eds) Varieties of Right-Wing Extremism in Europe. London and New York: Routledge, pp. 149-164.

Roy O (2016a) Beyond populism: the conservative right, the courts, the churches and the concept of a Christian Europe. In: Marzouki N, McDonnell D and Roy O (eds) Saving the People: How Populists Hijack Religion, London: Hurst \& Company, pp. 185-202.

Roy O (2016b) The French national front: from Christian identity to Laicité. In: Marzouki N, McDonnell D and Roy O (eds) Saving the People: How Populists Hijack Religion, London: Hurst \& Company, pp. 79-93.

Rydgren J (2017) Radical right-wing parties in Europe: what's populism got to do with it? Journal of Language and Politics 16(4): 485-496.
Schwörer J (2018) Right-wing populist parties as defender of Christianity? The case of the Italian Northern League. Zeitschrift für Religion, Gesellschaft und Politik 24(2): $387-413$.

Schwörer J and Romero-Vidal X (2020) Radical right populism and religion: mapping parties' religious communication in western Europe. Religion, State and Society 48(1): 4-21.

Schwörer J, Romero-Vidal X and Fernández-García B (2020) The religious dimensions of the Spanish radical right - ideology, communication and agenda setting of Vox. In: Hennig A and Weiberg-Salzmann M (eds) Religion and Illiberal Politics in Europe and Beyond: Concepts, Actors, and Identity Narratives. Frankfurt am Main: Campus. (fourthcoming).

Vasilopoulou S (2011) European integration and the radical right: three patterns of opposition. Government and Opposition 46(2): 223-244.

Zúquete JP (2017) Populism and religion. In: Kaltwasser CR, Taggart P, Espejo PO, et al. (eds) The Oxford Handbook of Populism. Oxford: Oxford University Press, pp. 445-466.

\section{Author biographies}

Jakob Schwörer is a $\mathrm{PhD}$ candidate and research fellow at the Institute for Political Science at the Leuphana University Lüneburg and teaches party politics, populism and political communication. In 2019 he was a visiting scholar at the Center for Research on Extremism (C-Rex) in Oslo. His research focuses on parties, populist and nativist communication of political actors in a comparative perspective. In 2019, his working paper 'Populistization of mainstream Parties' won the award for the best contribution among non-doctoral scholars at the annual conference of the Spanish Political Science Association (AECPA).

Belén Fernández-García is $\mathrm{PhD}$ in Political Science from the University of Granada (Spain) and currently researcher at the Institute of Social Sciences, University of Lisbon. She obtained a 5-yr Degree in Political Science and Public Administration with a National Award for Excellence in Academic Performance, and a Master degree in Problemas Sociales, Dirección y Gestión de Programas Sociales at the University of Granada. Her principal research interests lie in the area of political parties, populism, hate speech and disinformation. 